\title{
WIND DAMAGE TO BUILDINGS, INFRASTRUCUTURE AND LANDSCAPE ELEMENTS ALONG THE BEACH ROAD AT VISAKHAPATNAM
}

\author{
Mohan Kotamrazu ${ }^{1}$ \\ ${ }^{1}$ Senior Professor, Gitam School of Architecture, Gitam University, Visakhapatnam, Andhra Pradesh, India
}

\begin{abstract}
Cyclone Hudhud, which made its landfall at Visakhapatnam on $12^{\text {th }}$ October 2014, damaged a large number of buildings, industrial installations, severed electrical and communication lines and wiped out more than half of the city's green cover. The 27 $\mathrm{km}$ long stretch of the Visakha-Bheemli Beach road bore the major brunt of the cyclone. This paper reports the results of a visual study carried out by the author to assess the damage to buildings, infrastructure and hard and soft landscape along the VisakhaBheemli beach road and its vicinity. The study would be useful for understanding the vulnerability of these elements to cyclonic winds.
\end{abstract}

Keywords: Wind damage, buildings, infrastructure, hardscape elements, softscape elements.

\section{INTRODUCTION}

A visual assessment of the damage to buildings, infrastructure and landscape elements along the VisakhaBheemli coastal corridor has been carried out by the author over a period of three weeks in the after math of the cyclone Hudhud. The study aims to understand the impact of extreme winds on buildings, infrastructure and landscape

\section{DAMAGE TO BUILDINGS}

\subsection{Residential Buildings}

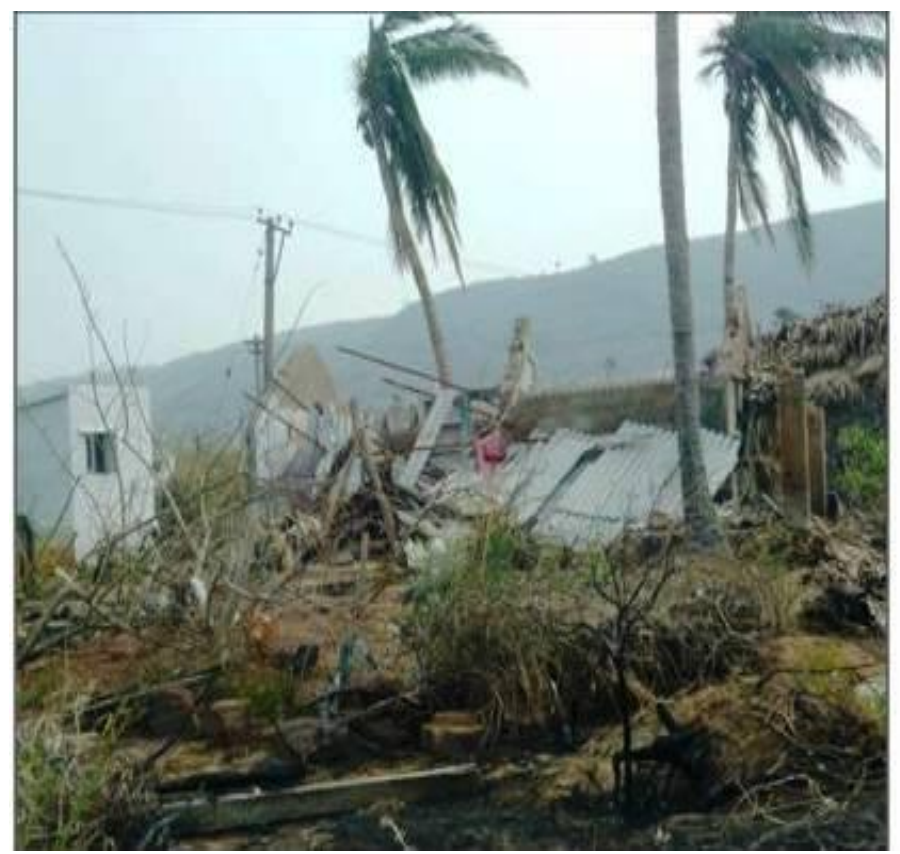

(a) elements in the face of extreme cyclonic winds. The results from post-damage studies would be useful to architects, planners and engineers in taking informed decisions for designing buildings and infrastructure that would be less vulnerable to damage by strong winds. It would also help in the selection of trees that are wind resistant and more resilient to damage from future storms.

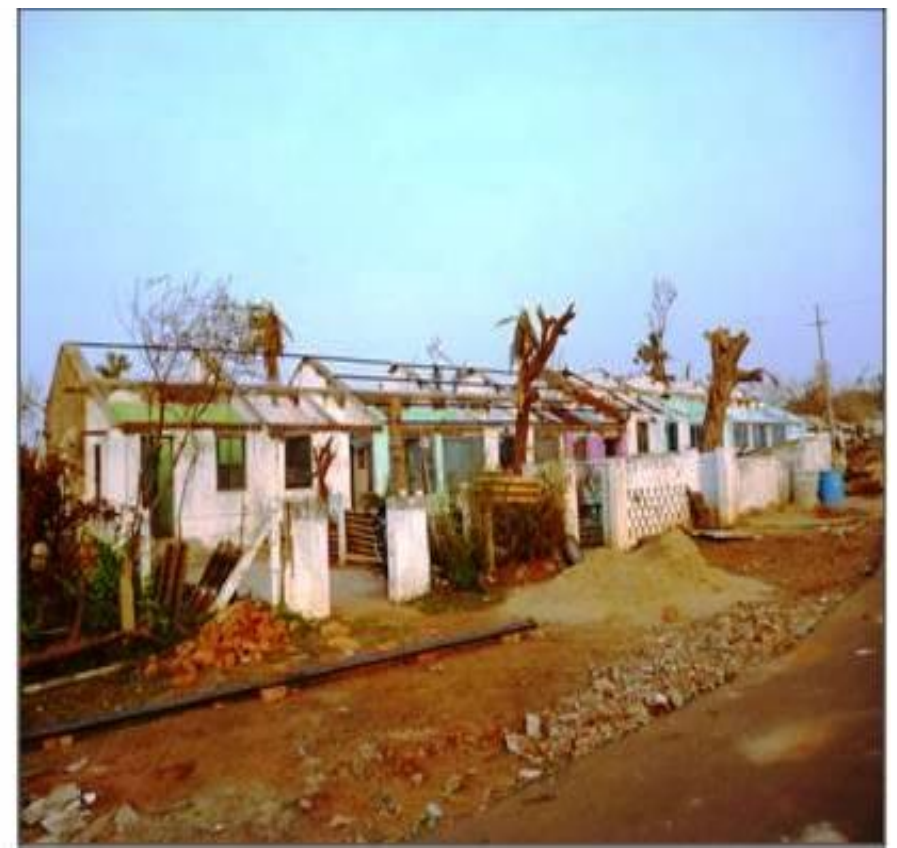

(b)

Fig 1 (a) A house with collapsed roof at Bheemunipatnam (b) Damage to the Non-Teaching staff quarters of Andhra University. 
Many residences built with semi- permanent materials and roofs with A.C. sheets suffered extensive wind damage. Figure1 (a) shows a building with a collapsed roof located along the Visakha-Bhimli Beach Road near Bheemunipatnam. The badly battered quarters NonTeaching staff quarters of the Andhra University are shown in Figure 1(b). Several houses in Sagar Nagar, Visalakshi Nagar and on the base of the Kailasha Hill got badly bruised with broken porticoes, parapets and balcony railings. Figure 2 (a) shows the damaged portico in a residence exposed to

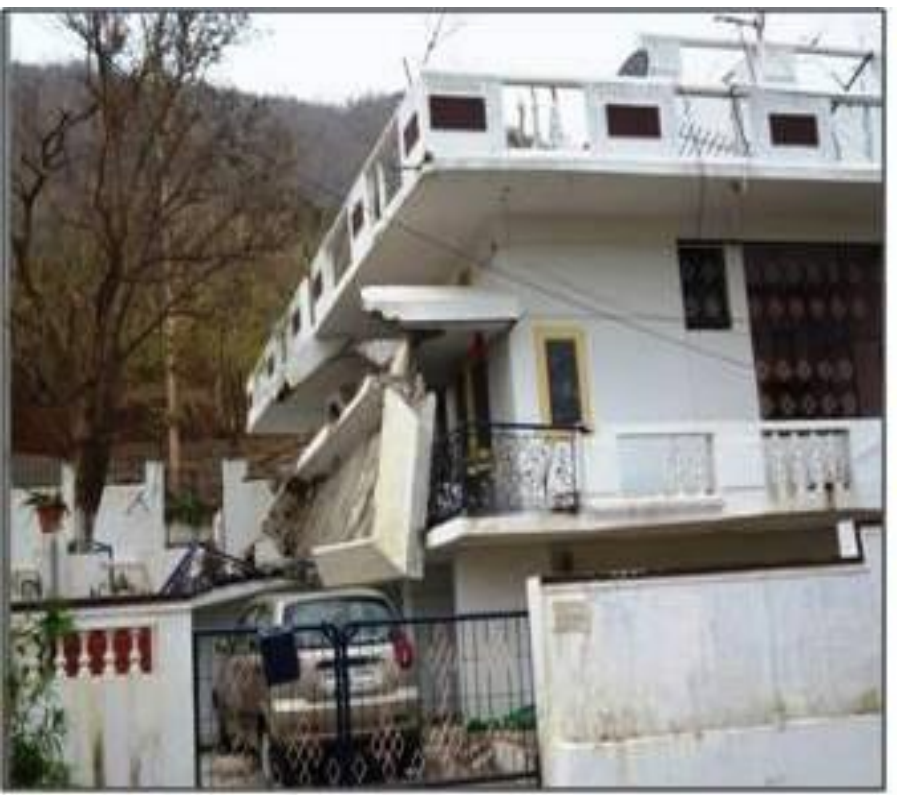

(a) the direct assault of wind at the base of the Kailasha hill. All the other buildings in the wake of this building were unaffected.

The facades of several apartments have incurred damage and the compound walls in two apartments have been damaged substantially. Several balconies, parapets of the bluff bodied Arihant Apartments have been damaged by strong winds whereas the streamlined balconies of the adjacent Sunrise Apartments were unaffected 2(b).

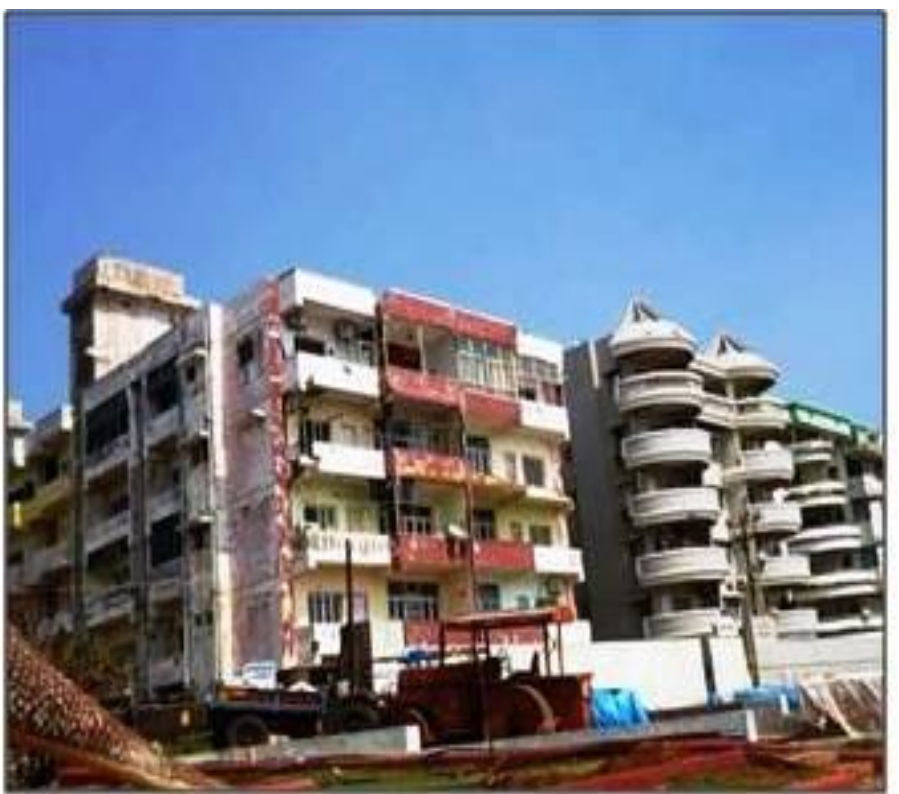

(b)

Fig 2 (a) Damage to the portico in a residence at the base of Kailashgiri (b) Damage to windows, glass screens and balcony parapets in Arihant Apartments on the Beach Road

\subsection{Hotels and Restaurants}

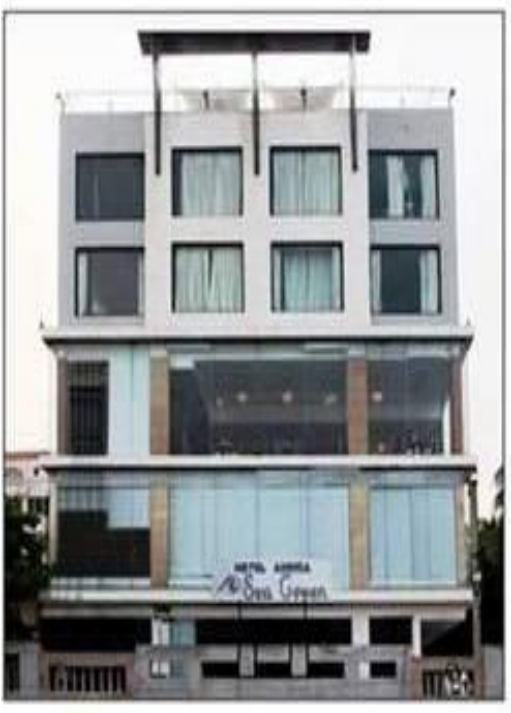

(a)

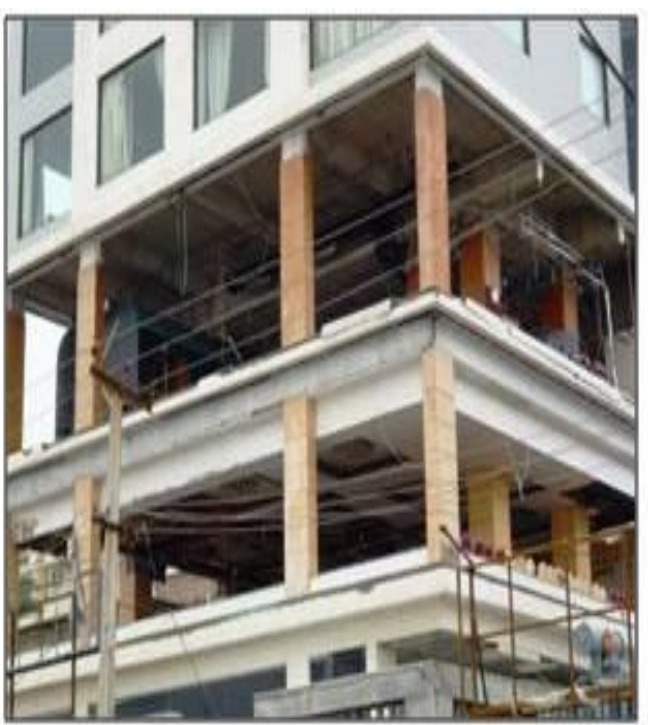

(b)

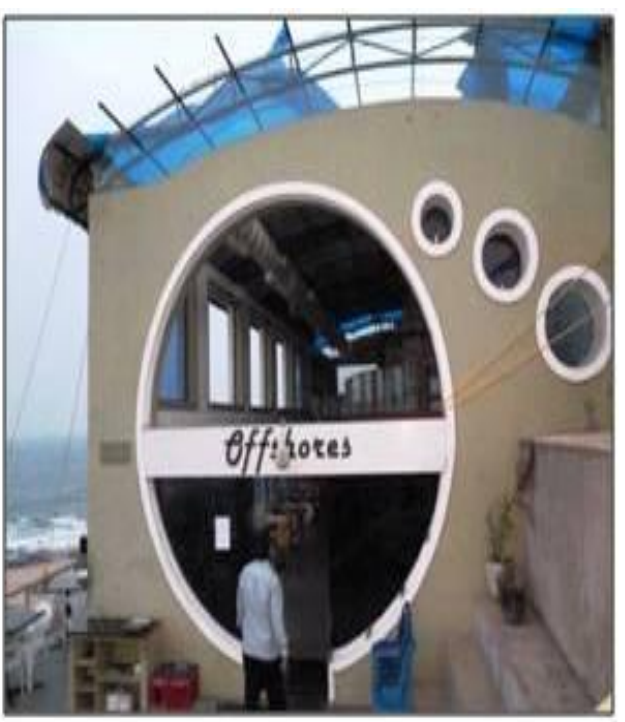

(c)

Fig 3 (a) View of the Hotel Ambica Sea Green at Kirlampudi Layout before the cyclone. (b) Shattered glass panels in second and third floor of Ambica Sea Green post Hudhud.(c) Wind damage to glass windows and roof cladding of Vihar restaurant on Rushikonda Hill. 
Several hotels and restaurants that have recently sprung up along the Beach Road such as the Novotel Hotel near Ramakrishna Beach and Rushikonda Hill sport large glass facades to capture the sea view. While Novotel Hotel was only slightly affected, Hotel Ambica Sea Green and Vihar restauran suffered appreciable damage (View of the Hotel Ambica Sea Green is shown in Figure 3(a). The damaged glass wall panels in the banquet hall and the restaurant in the first and second floors respectively is shown in Figure 3(b). Figure 3(c) gives a view of the damaged roofing sheets and glass panels in the façade of the Vihar restaurant on the Rushikonda hill.

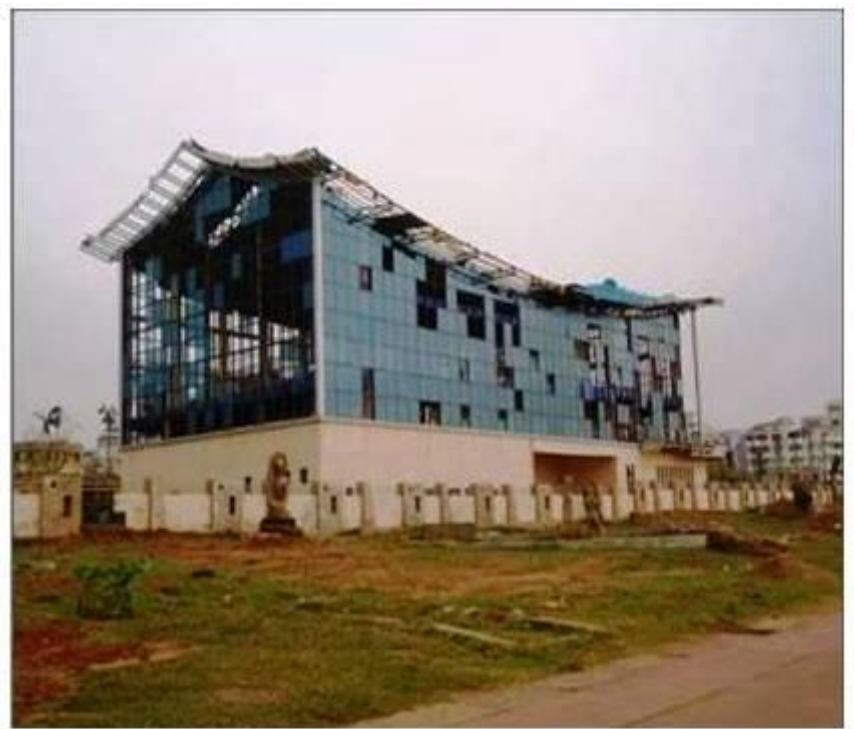

(a)

\subsection{Exhibition Halls and Indoor Stadiums}

Damage to the glass facades and false ceilings has been observed not only in buildings in the vicinity of the Beach Road but also in many other car showrooms elsewhere in the city. One such building where the entire false ceiling got ripped off is the Visakhapatnam airport. Figure 3(a) shows the damage to the glass walling and roof cladding in the Rajiv Smruti Bhavan, an exhibition hall located along the Beach Road.View of the Indoor Sports stadium in the Gitam University campus showing damage to roof cladding is shown in Figure 3(b)

Fig 3 (a) View of the damaged glass wall panels and roof cladding in the Rajiv Smruti Bhavan, on the Beach Road. (b) Damage to the Indoor sports stadium at Gitam University.

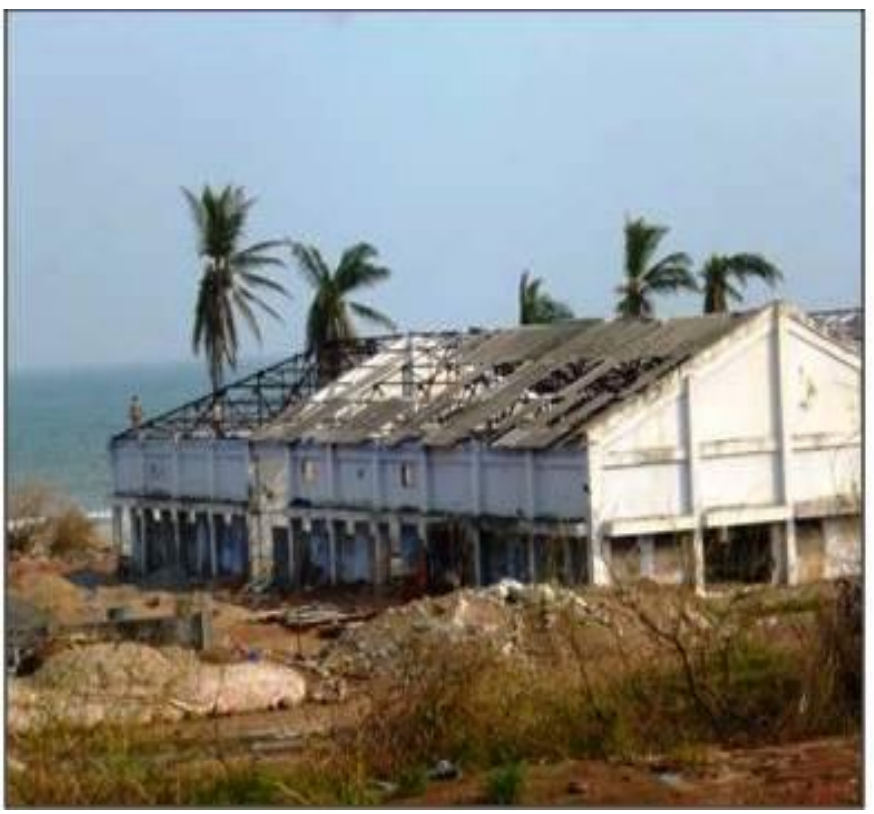

(a)

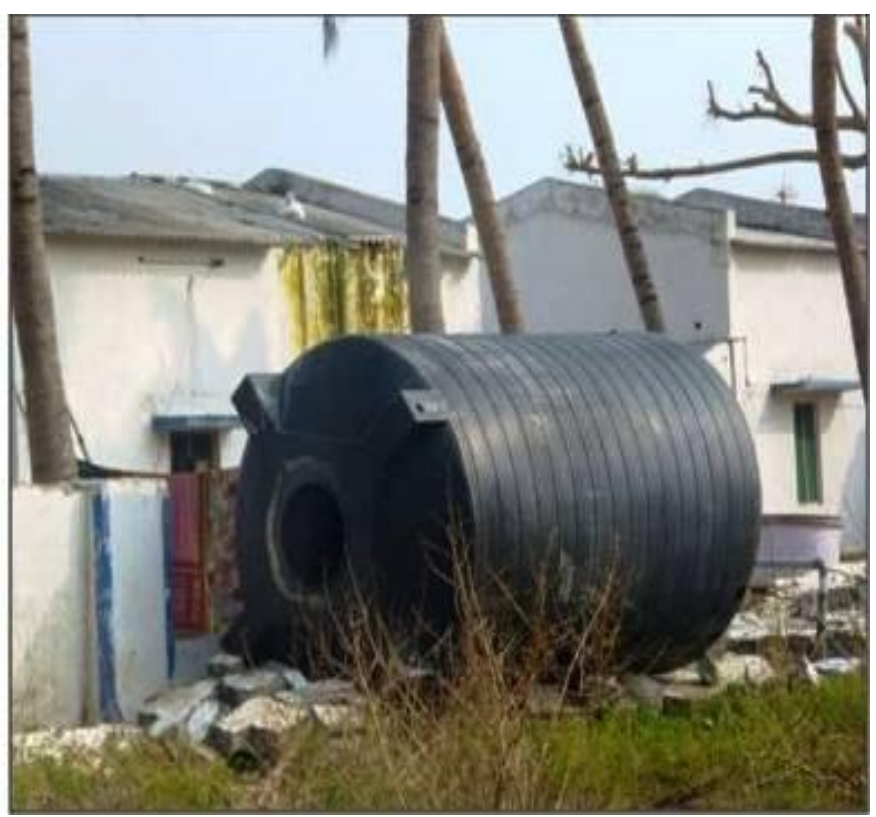

(b)

Fig 4 (a) A damaged hatchery building near Thotlakonda. (b) A collapsed water tank in front of a Hatchery building near Thotlakonda. 


\subsection{Hatcheries}

A large number of hatcheries located along the Beach Road beyond Thotlakonda bore the full impact of the cyclonic winds. Most of the roof cladding materials has been extensively damaged and in some cases the roofs have been completely blown away Figure 4 (a) shows a hatchery building with damaged roof cladding. Figure 4(b) shows a grounded water tank in front of another hatchery building near Thotlakonda.

\subsection{Museums and Landmarks}

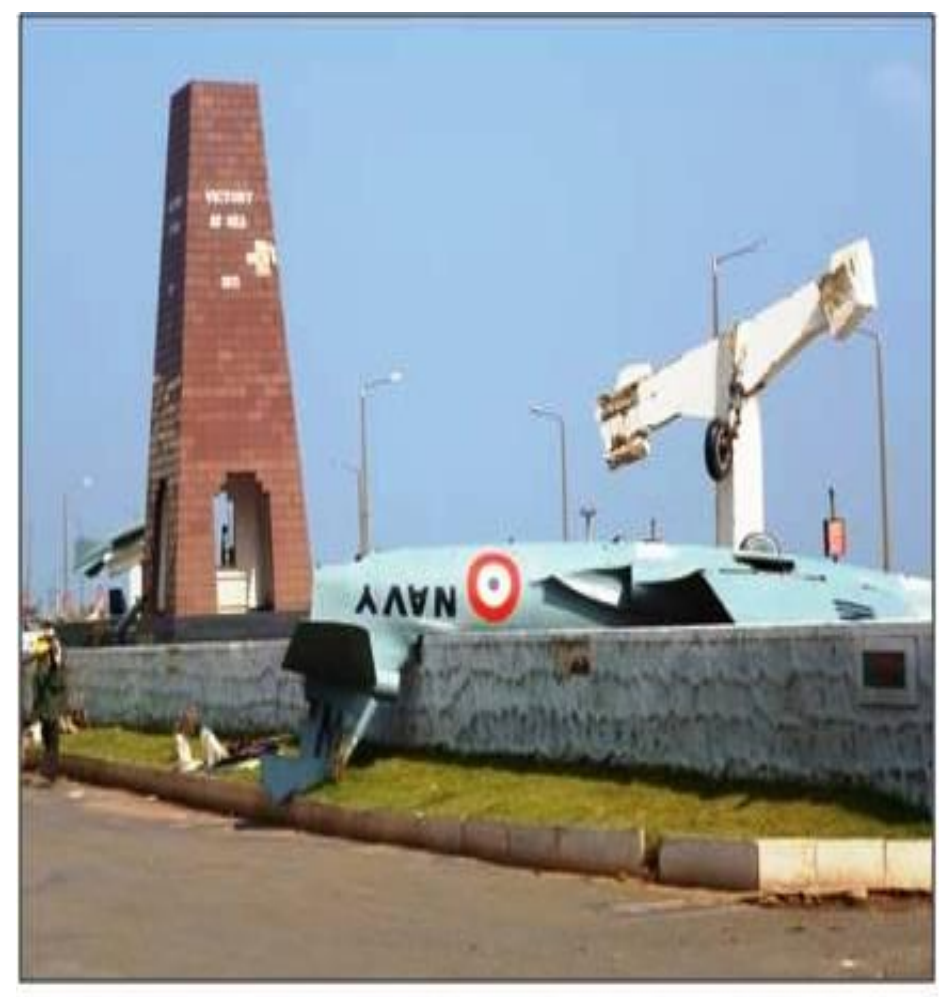

(a)

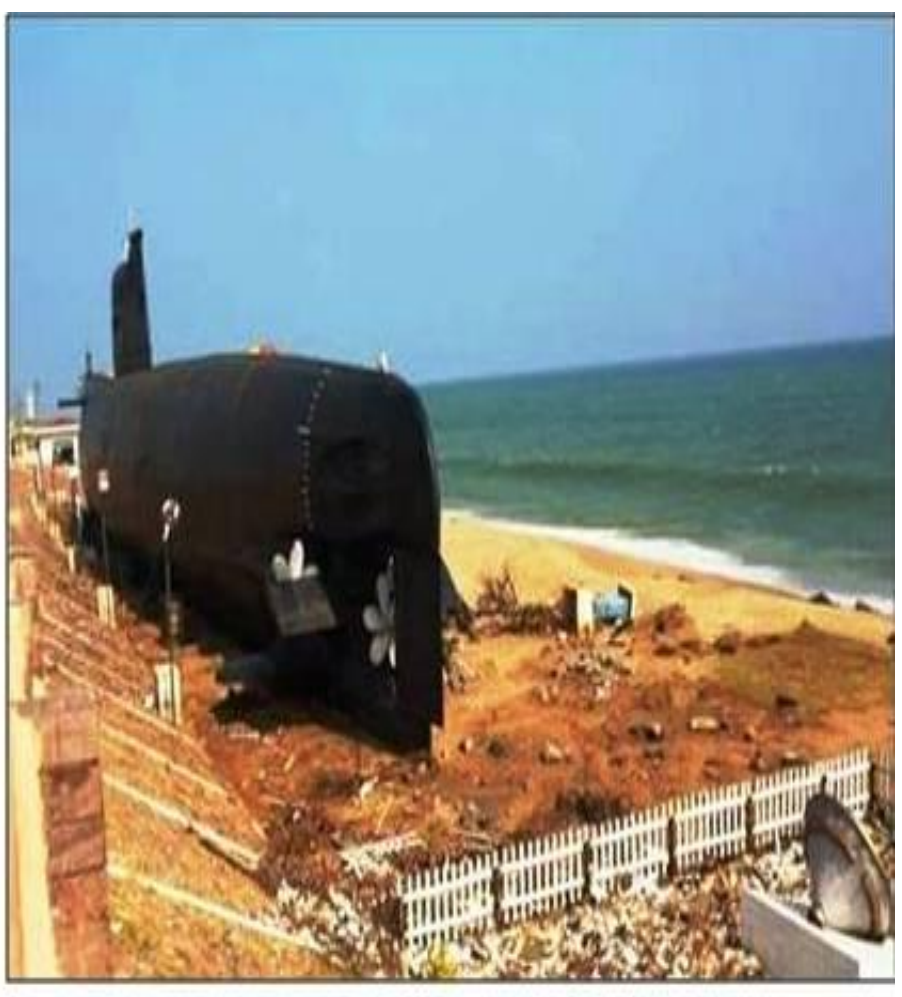

(b)

Fig 5 View of a fallen warplane replica in the landmark war memorial park at Kirlampudi Layout. (b) View of the submarine museum Kursura after the cyclone.

In the aftermath of Cyclone Hudhud, erosion is being witnessed all along the coast, including behind Vuda Park, near the Lighthouse at East Point Colony and also along the beach at Bheemunipatnam. According to oceanography experts the beach around Kursura, the only submarine museum in South Asia may experience further erosion. Figure 5(b) shows the damage to the park in front of the submarine museum. Earlier a protection wall and a belt of casurina trees served as a defence for the submarine, which got wiped out by the cyclone. The area in front and behind Kursura is witnessing more erosion. The sea side stretch is now open and has become inaccessible to visitors. The museum is now temporarily closed.

\subsection{Infrastructure}

According to newspaper reports (The Hindu; Oct14, 2014) the wind speed that hovered around 180 to $200 \mathrm{kmph}$ from morning to late evening brought down about $1026(33 \mathrm{kv})$ poles, 4,400 $(11 \mathrm{kv})$ and 5,900 LT poles in the three districts of Visakhapatnam, Srikakulam and Vijayanagaram. Nearly 10,000 broadband connections out of the 40,000 connections were affected by the impact of the cyclone in
Visakhapatnam. Figure 6(a) shows a fallen electric pole blocking the road in the residential area of Kirlampudi Layout. Figure 6 (b) shows the twisted streetlights on the Beach road beyond Rushikonda. Though the poles remained intact the luminaires on all the poles have been twisted to the other side due to the torque effect exerted by the cyclonic winds. Figure 7(a) shows a damaged pavement along the Beach road near Coastal Battery and 7(b) shows a pavement damaged by an uprooted Terminalia catappa tree at Vuda Park. Views of damaged bus shelters are shown in Figure 8. 


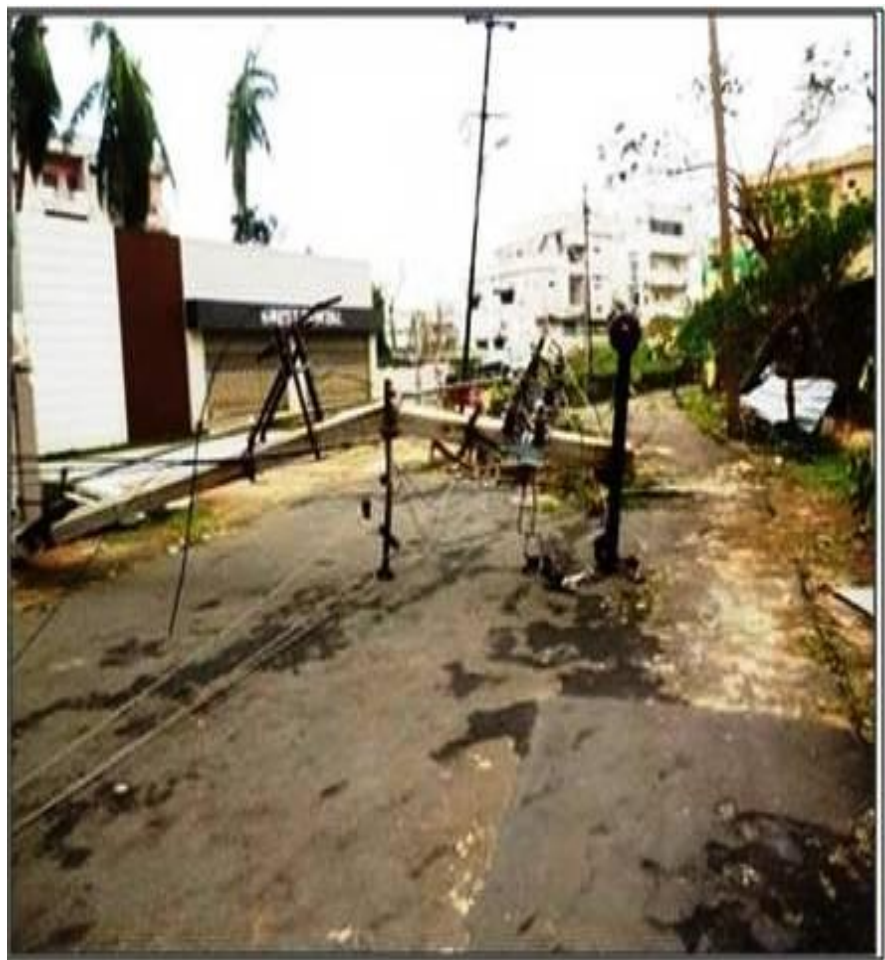

(a)

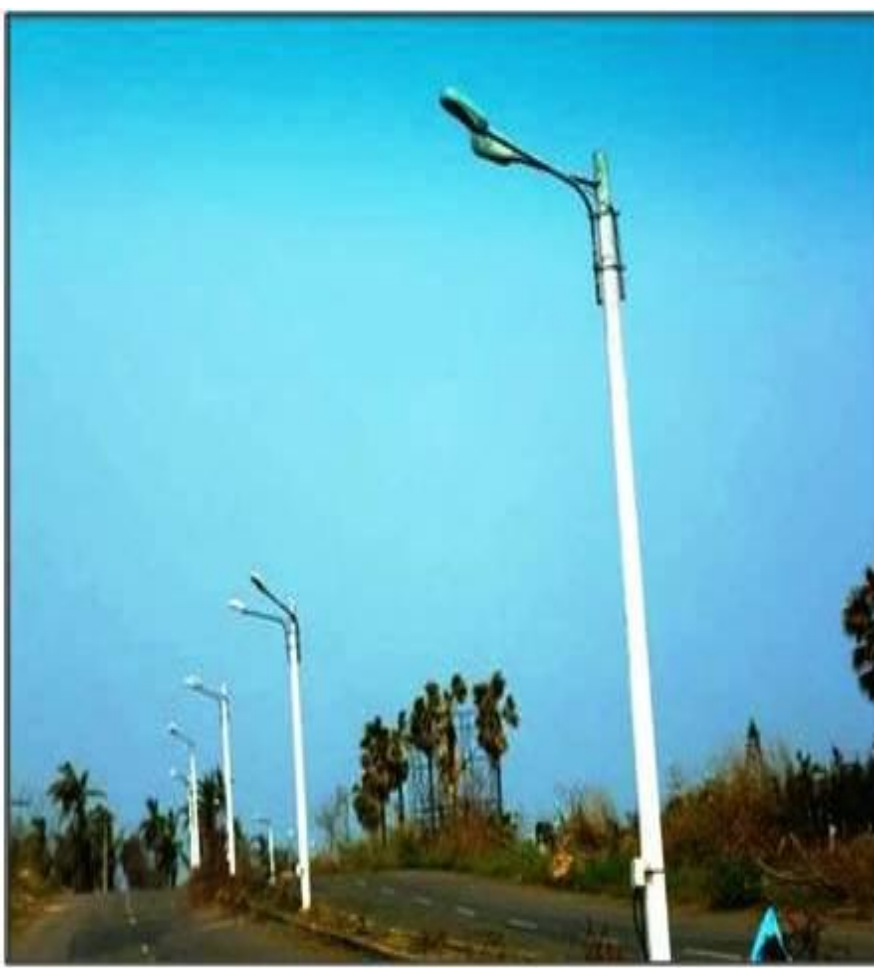

(b)

Fig 6 (a) Grounded electric poles block the road at Kirlampudi Layout (b) View of the wind twisted street lights along the Beach Road beyond Rushikonda.

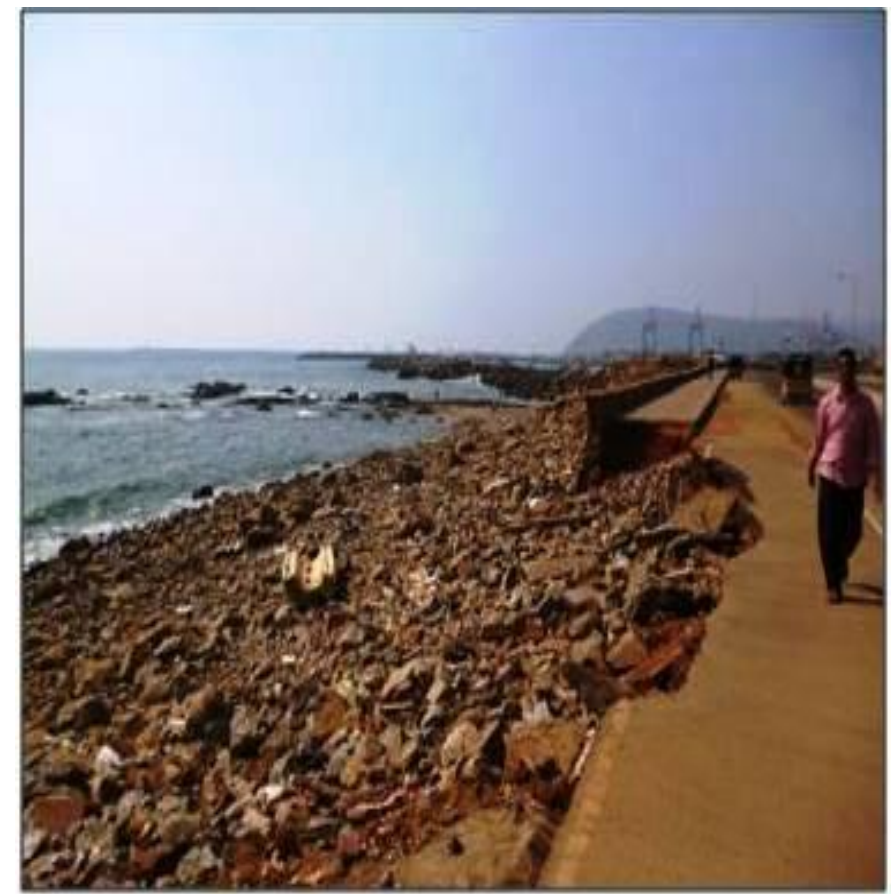

(a)

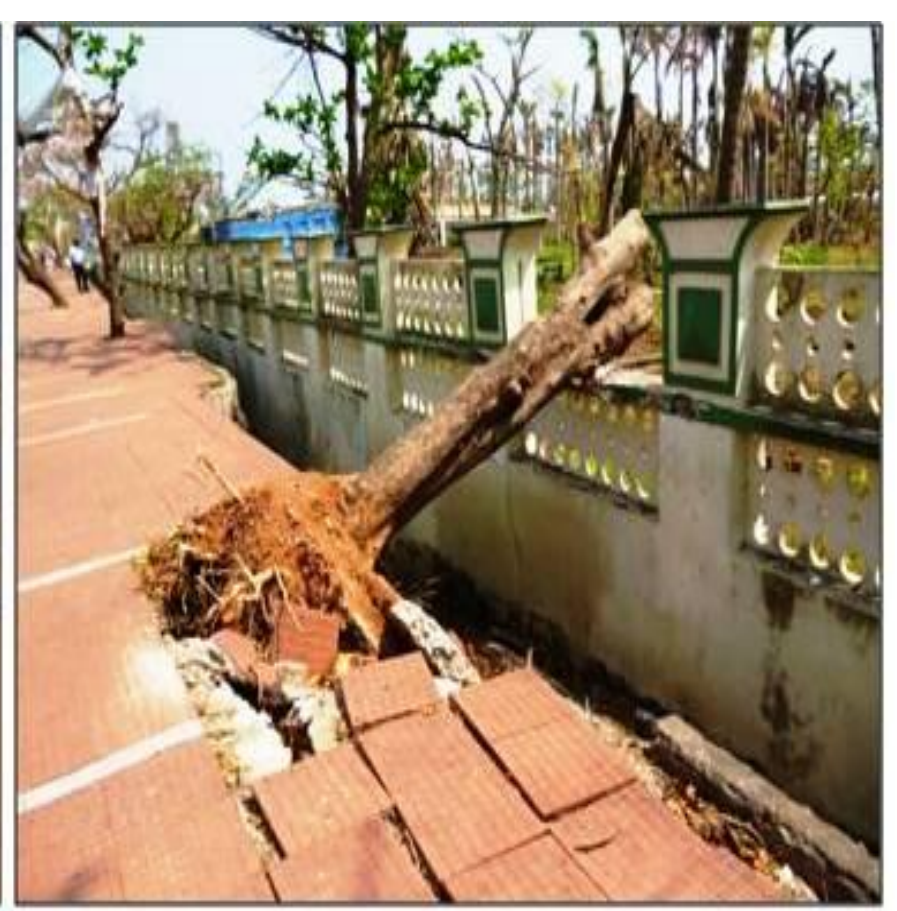

(b)

Fig 7 (a) Damaged pavement along the Beach road near Coastal Battery. (b) Pavement damaged by an uprooted Terminalia catappa tree at Vuda Park. 


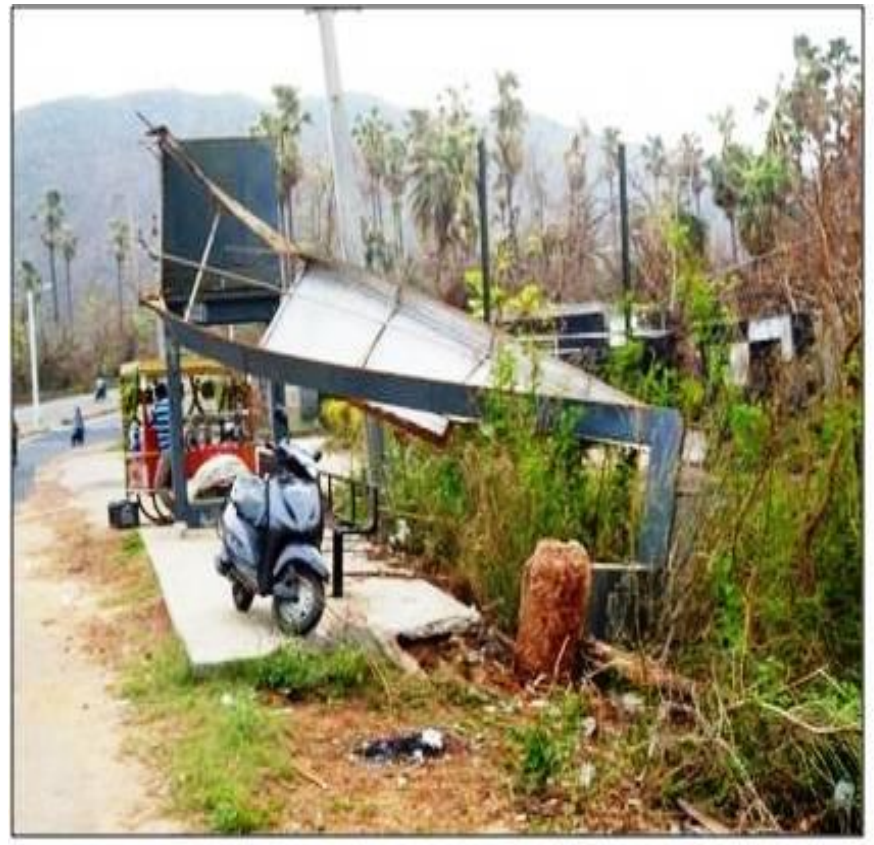

(a)

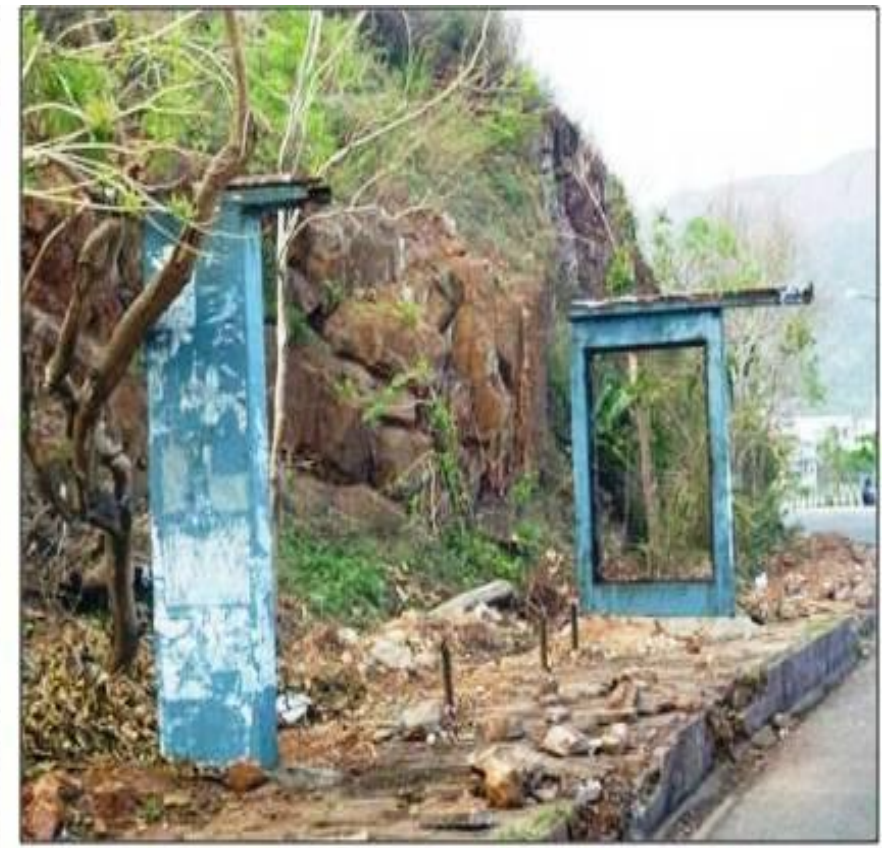

(b)

Fig 8 (a) A damaged bus shelter in front of the Indira Gandhi Zoological Park near Rushikonda. (b) A bus shelter with damaged roof and seats opposite Tenneti Park along the Beach Road.

\subsection{Hardscape Elements}

Hardscape elements comprise of the non- living elements in the landscape such as rocks, paving materials, street furniture, lighting fixtures and other utility elements. Damage to the hardscape elements in Tenneti Park, Shivaji Park and a park in Bheemunipatnam are shown Figures 9, 10, and 11 respectively.

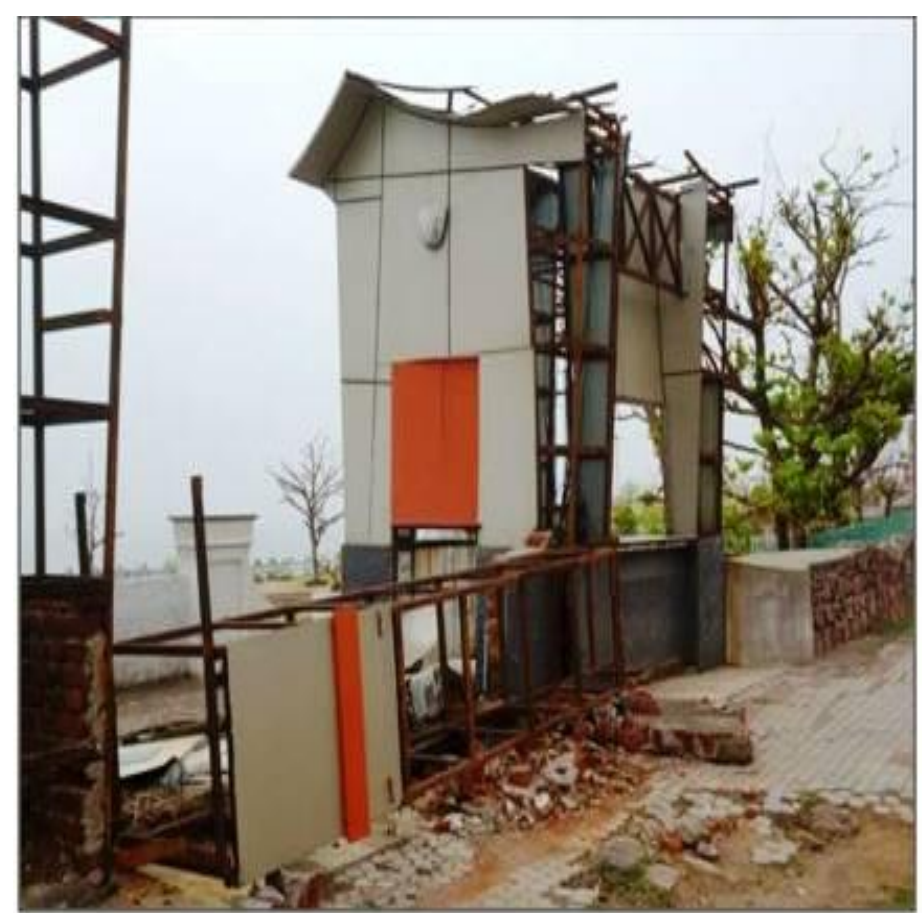

(a)

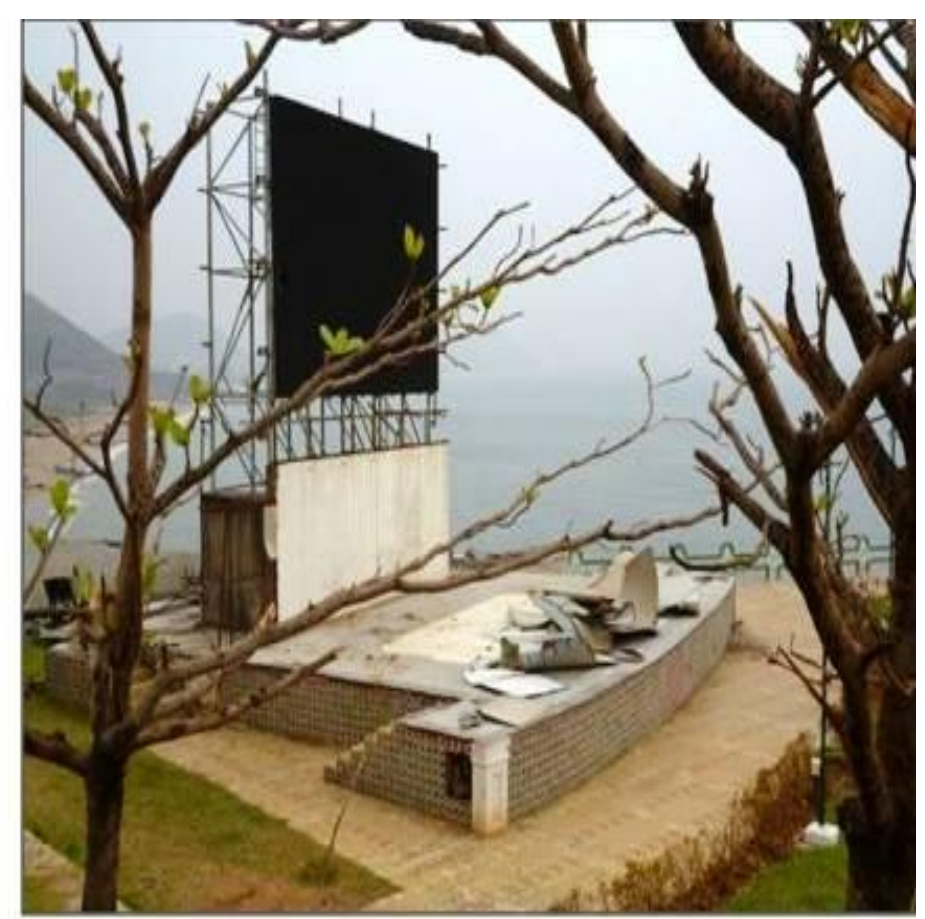

(b)

Fig 9 (a) A damaged ticketing counter at the entrance of Tenneti Park (b) Damaged amphitheatre in Tenneti Park. 


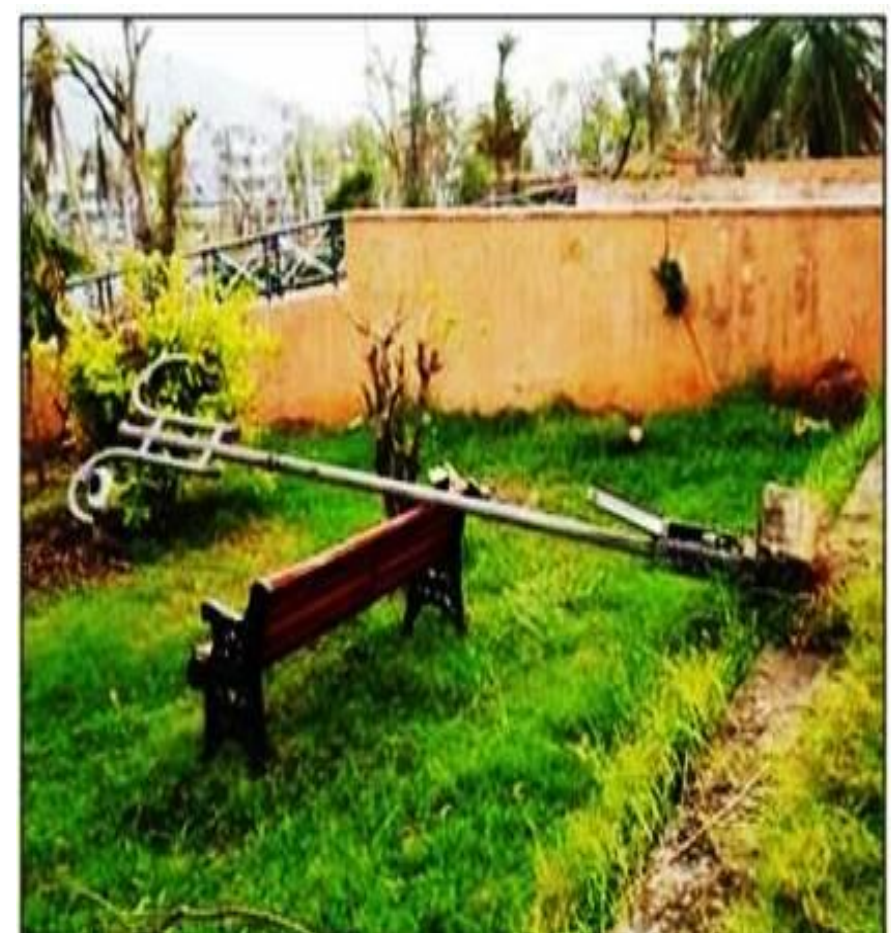

(a)

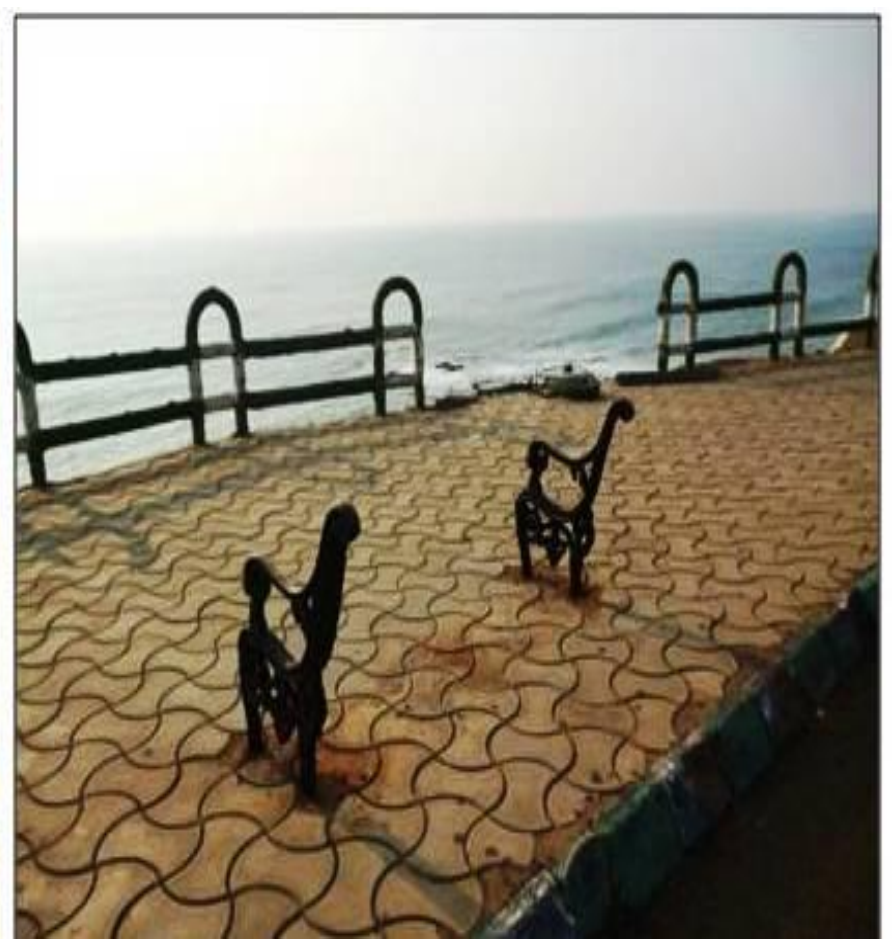

(b)

Fig 10 (a) Fallen lamp post in Shivaji Park (b) Damaged bench in Tenneti Park

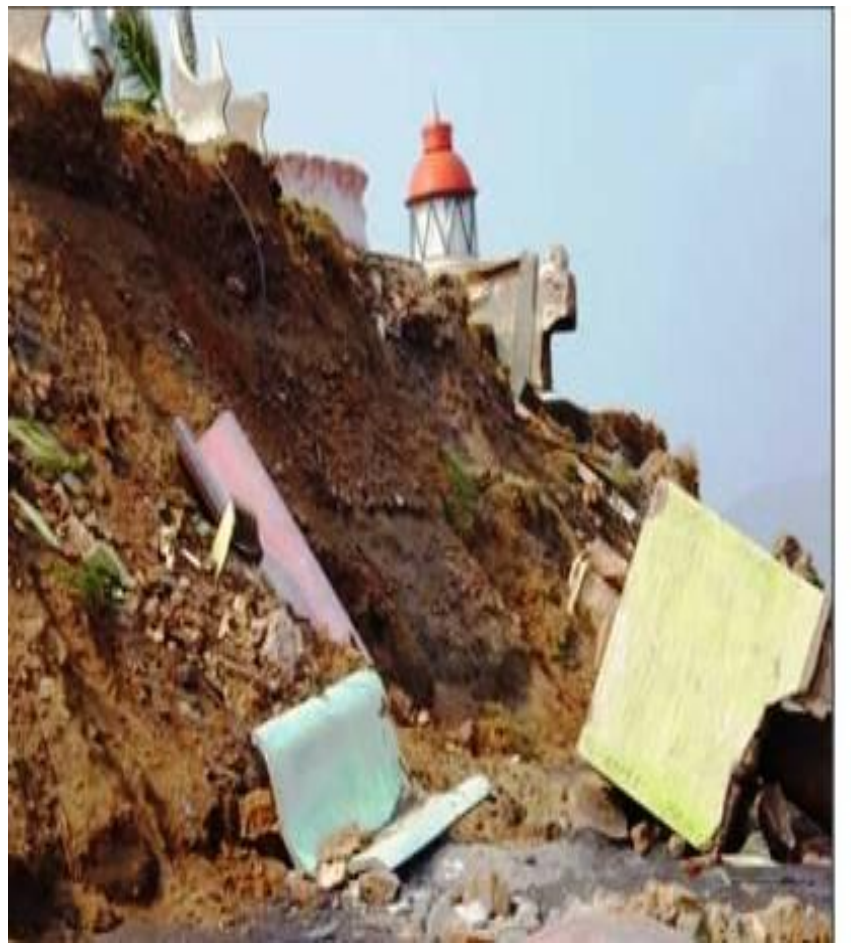

(a)

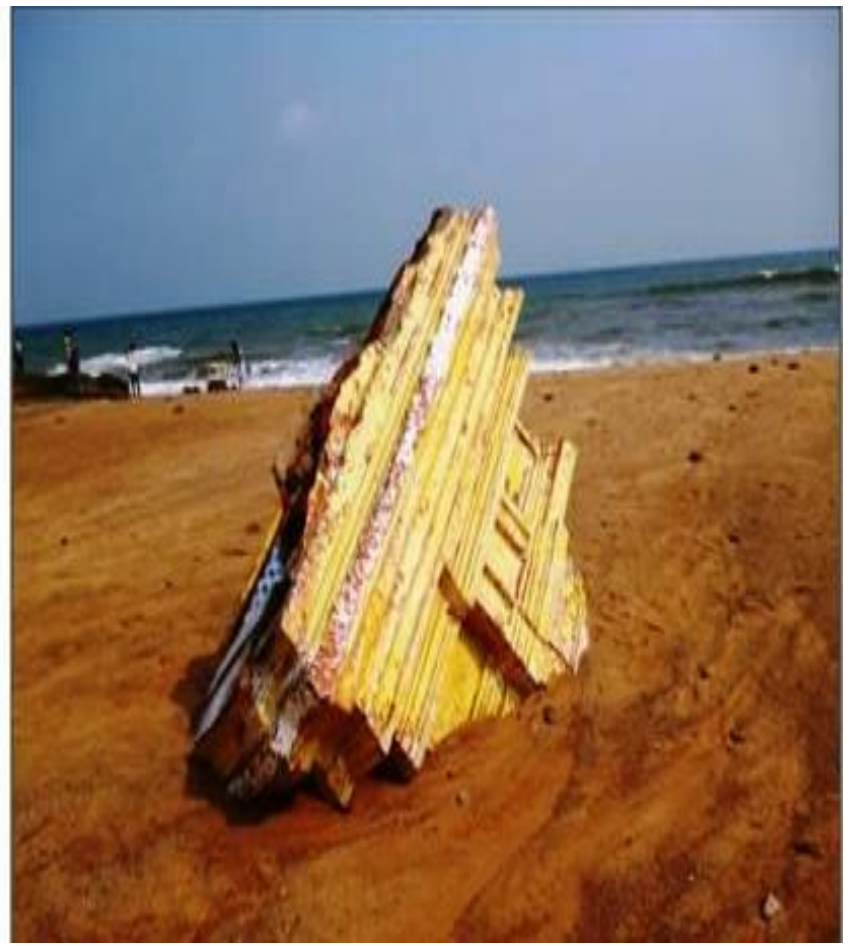

(b)

Fig 11 Damaged hardscape elements in a park at Bheemunipatnam. 


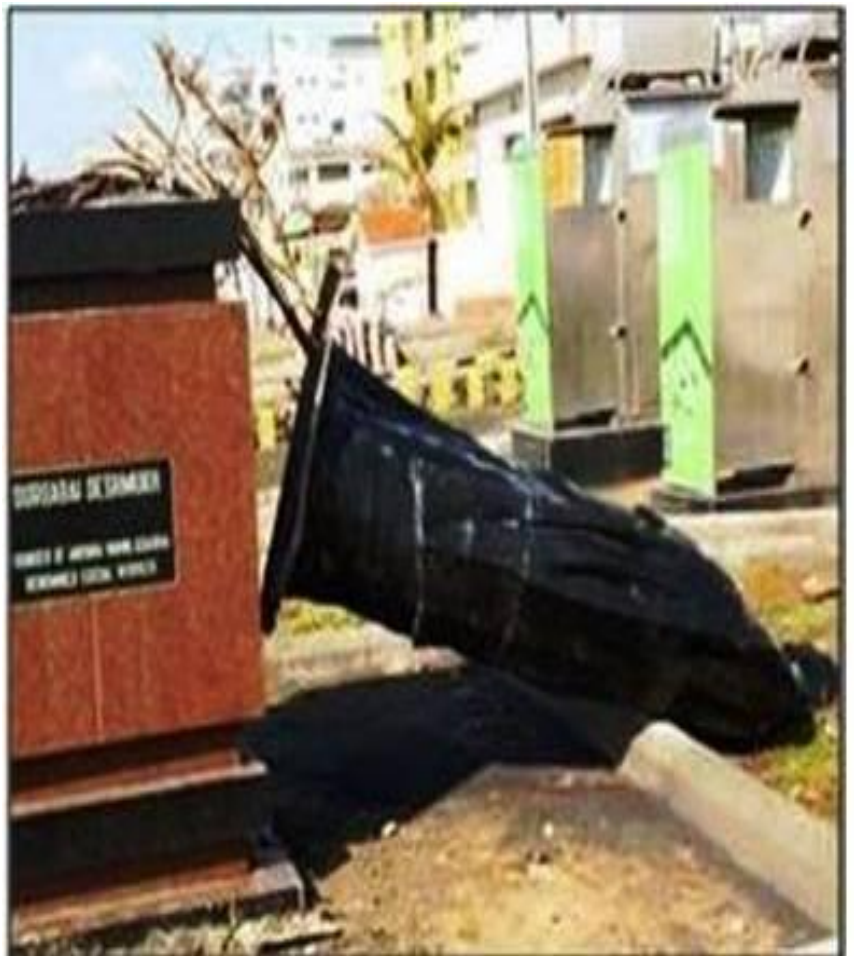

(a)

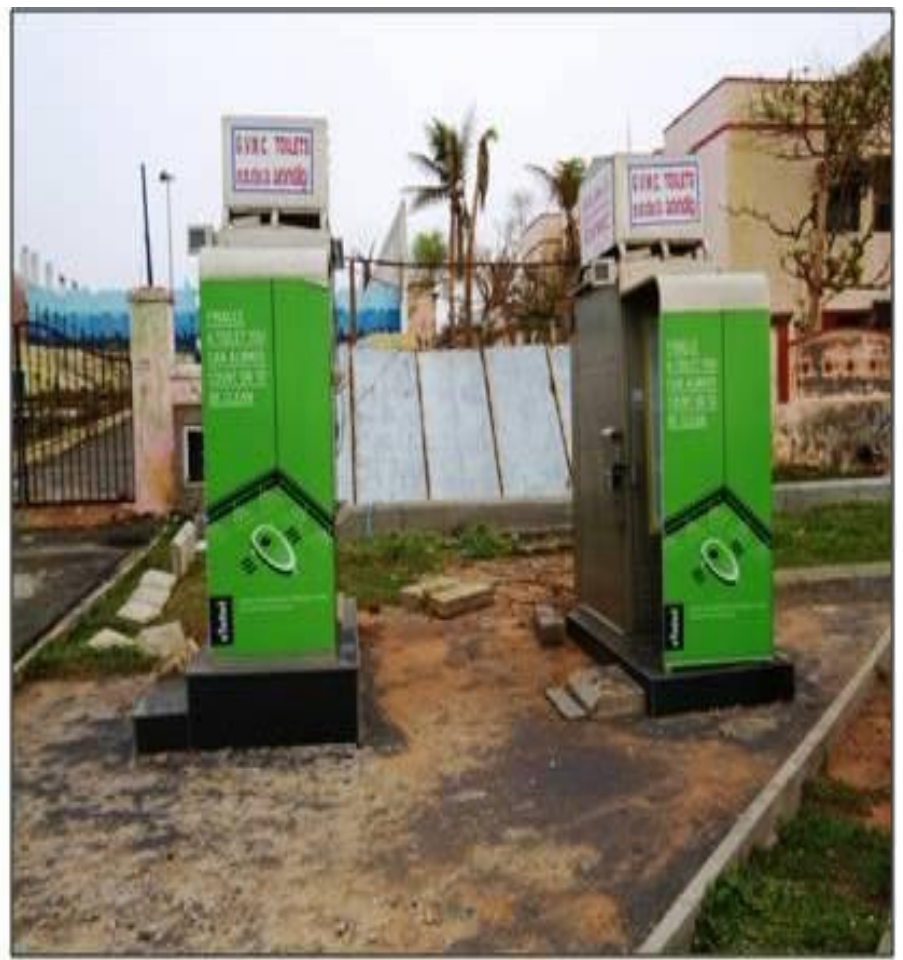

(b)

Fig 12 (a) View of a statue that fell on the Beach Road. (b) View of two E-toilets on the beach road adjacent to the fallen statue ,that stood up to the fury of the cyclone.

A view of a collapsed statue along the Beach Road is seen in Figure 10 (a). Figure (b) shows two E-toilets set up as public conveniences by the Greater Visakhapatnam Municipal Corporation and designed to withstand extreme winds. These toilets, designed by a Kerala based company stood up to the fury of the cyclone without getting damaged, while the hoardings in the rear of the toilets collapsed. Made of steel these toilets have been designed to provide pre-flushing prior to entry and sensors for water. Several such toilets are proposed to be set up in the Vuda Park.

\subsection{Softscape Elements}

Softscape elements comprise living elements such as trees, shrubs and groundcovers in a landscape. More than half the ground cover in Visakhapatnam was damaged by Hudhud.. Thousands of trees were either uprooted, suffered from broken stems or limbs or were partially damaged. Mohan et al. (2014) carried out an extensive survey of the damage inflicted on the trees along the Beach Road, two universities and four major parks in the city. This study shows that maximum damage has occurred to fast growing trees with shallow roots and brittle codominant stems like Peltophorum pteracarpum and Acacia auriculformis. Most of the Peltophorum trees planted along the highways and major roads and residential colonies in the city have either been uprooted or extensively damaged, blocking roads and damaging electrical installations. Unlike earthquakes, cyclones can be predicted in advance with the help of early warning systems. A few days before Hudhud made its landfall most of the massive roadside Peltophorum trees were pruned indiscriminately to prevent damage to power lines. Removal of the central part of the canopy or one side of the canopy damages the tree structure, affecting its structure and stability, making it vulnerable to storm damage. Figure 13. (a) shows an indiscriminately pruned roadside Peltophorum tree and Figure 13.(b) shows a collapsed Peltophorum tree striking the compound wall of a residence in Lawson's Bay colony.

Many massive Eucalyptus, Peltophorum and Ficus religiosa trees have been uprooted in the Andhra University campus. Several mature uprooted Eucalyptus trees have fallen on top of buildings and in some cases even crushing them ( Figure 14(a). Extensive damage has also occurred to the green cover at the Gitam University campus in Visakhapatnam. Figure14 (b) shows salt spray damage to the Callophyllum ionophyllum trees (left) and the Tecoma castinifolia and Azadrachta indica ( Neem) trees (right) in the Gitam University Campus at Visakhapatnam. 


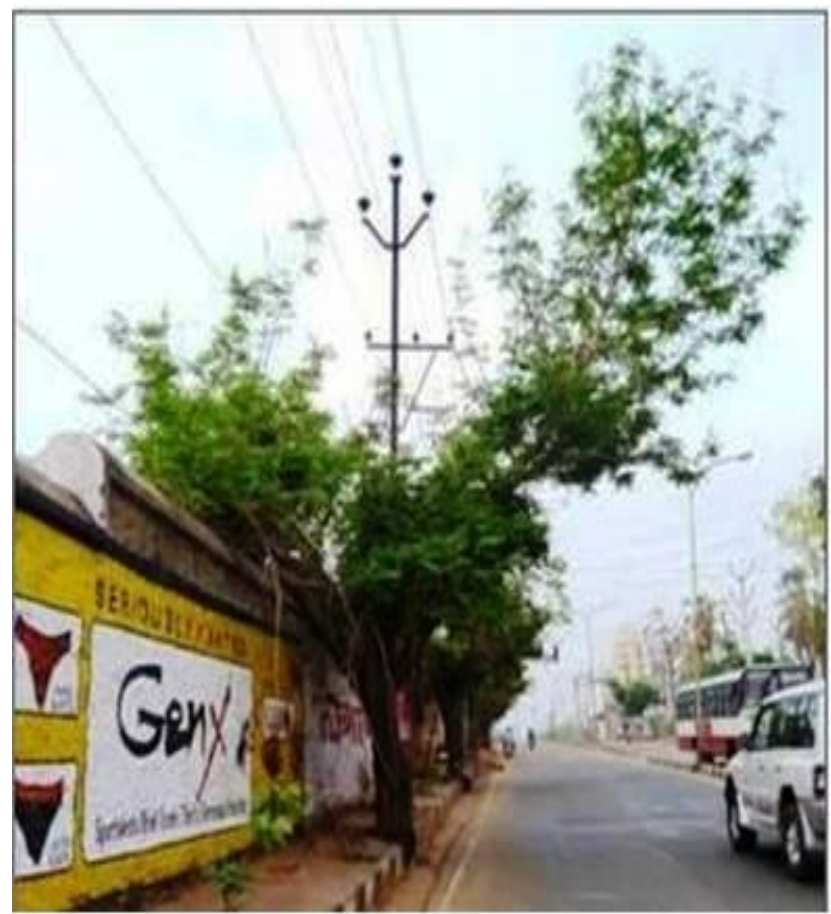

(a)

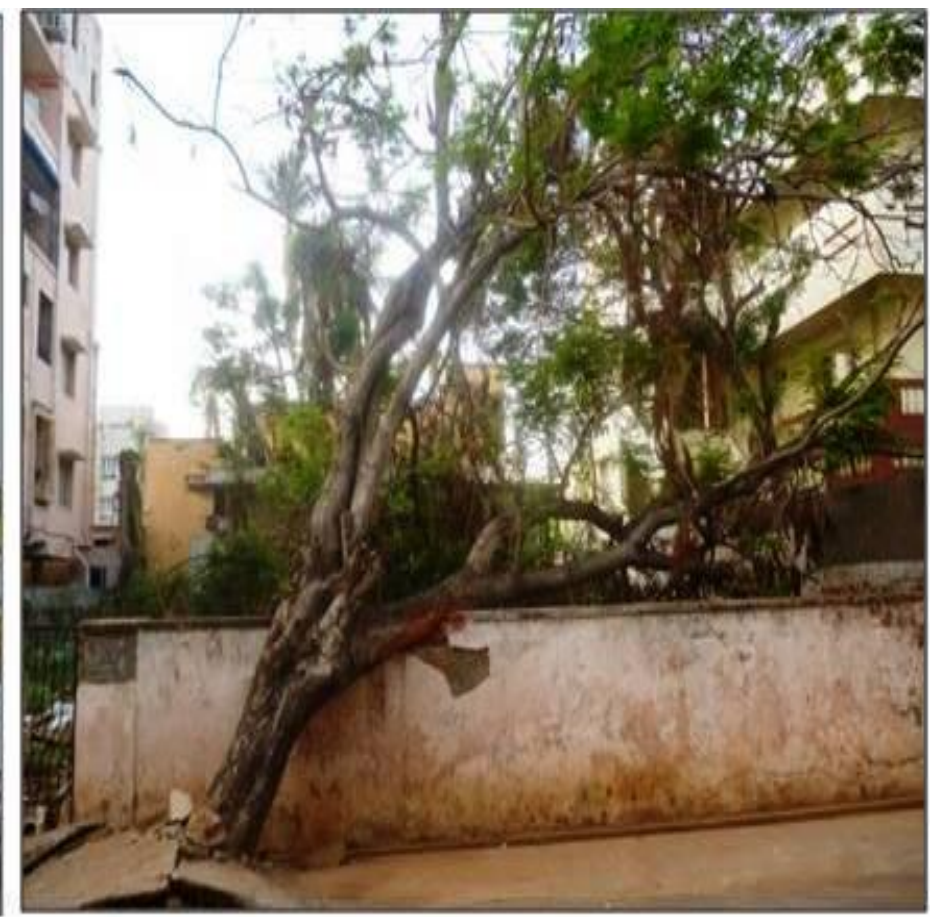

(b)

Fig 13 (a) A roadside Peltophorum tree indiscriminately pruned to prevent damage to power lines. (b) A leaning Peltophorum tree in Lawson's Bay colony.

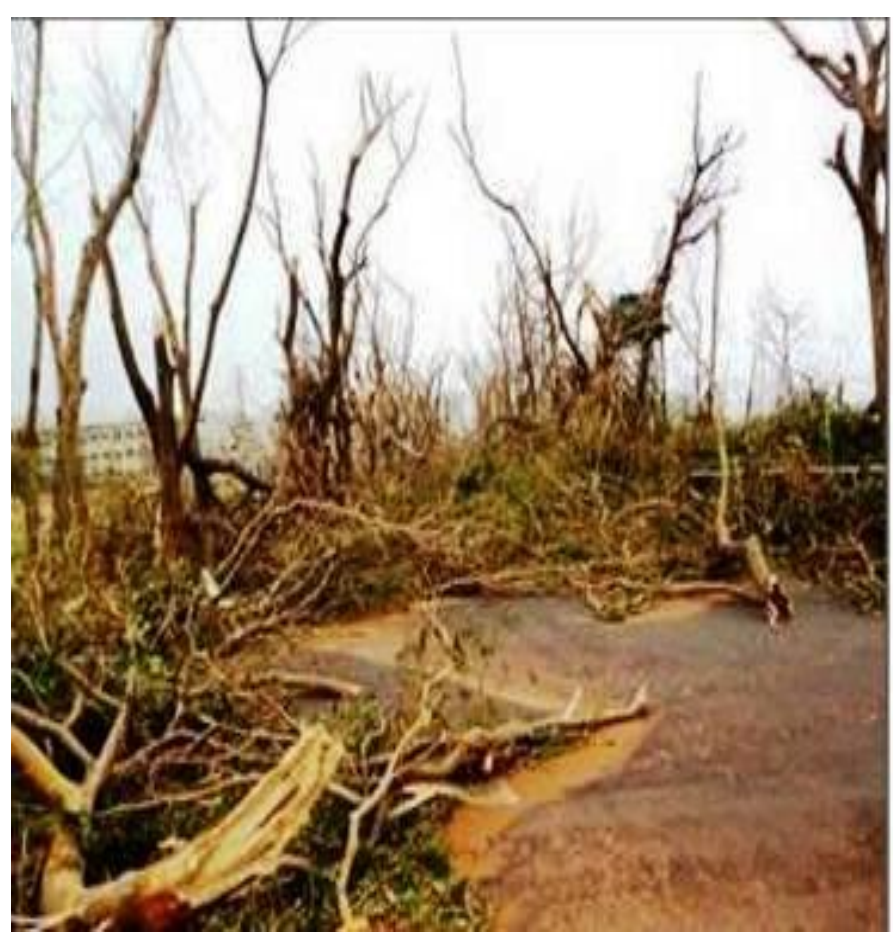

(a)

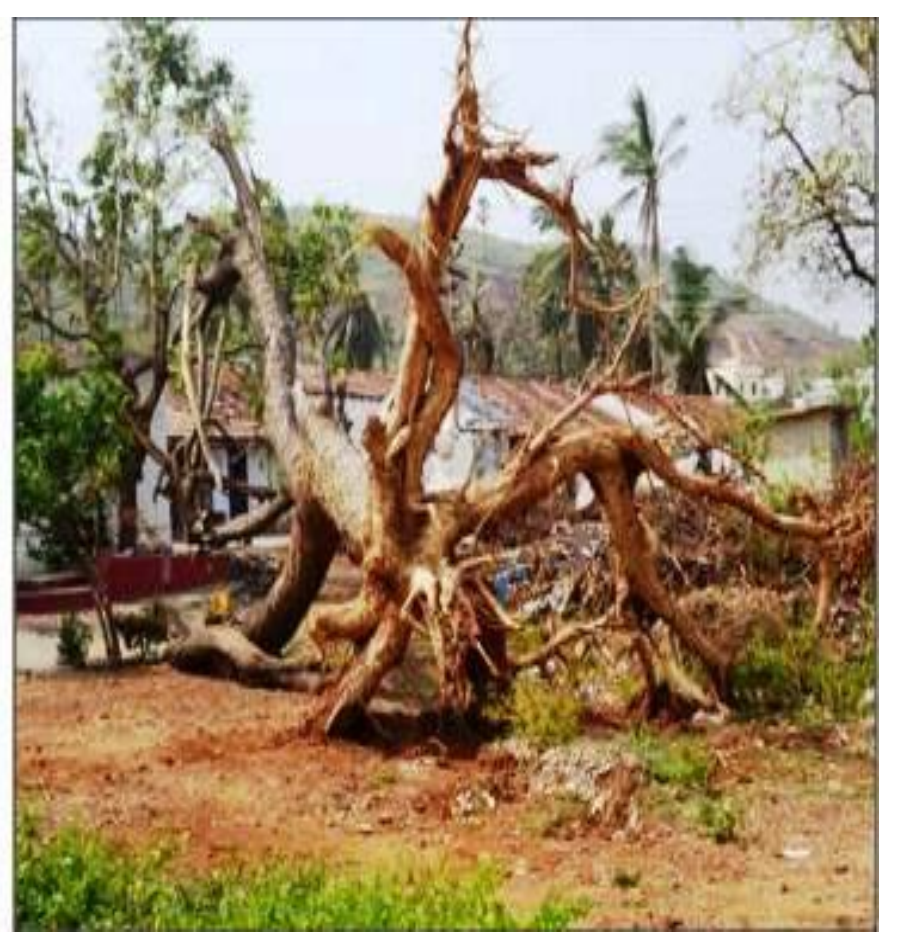

(b)

Fig 14 (a) Damaged Peltophorum trees in the Gitam University campus. (b) An uprooted Peltophorum tree in a village near Bheemunipatnam. 


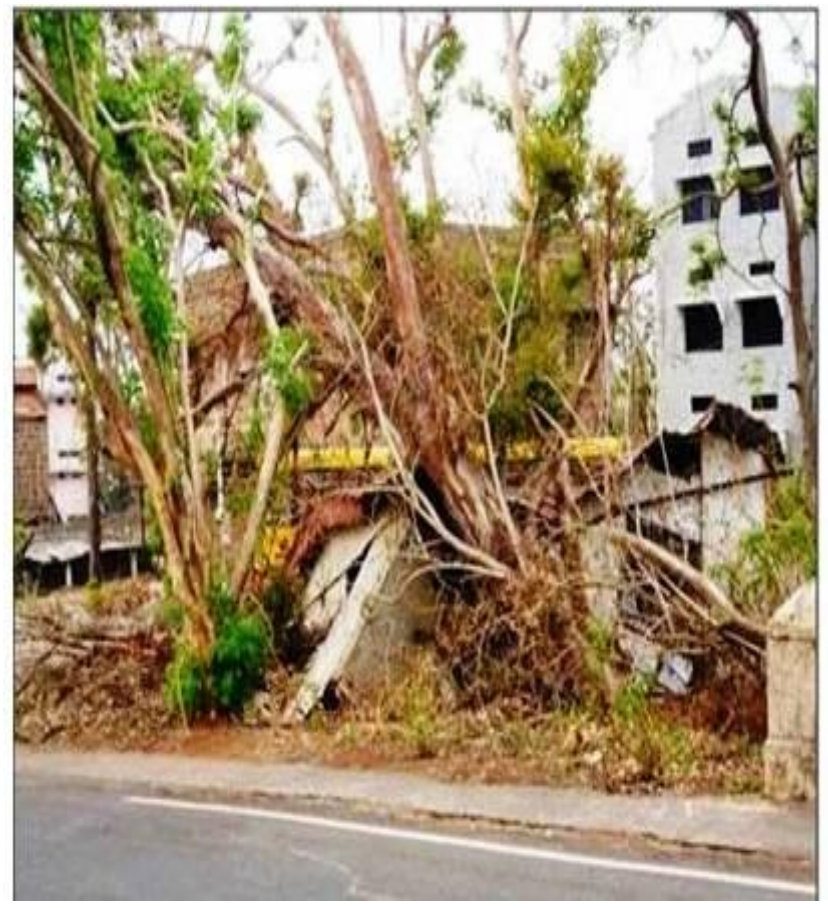

(a)

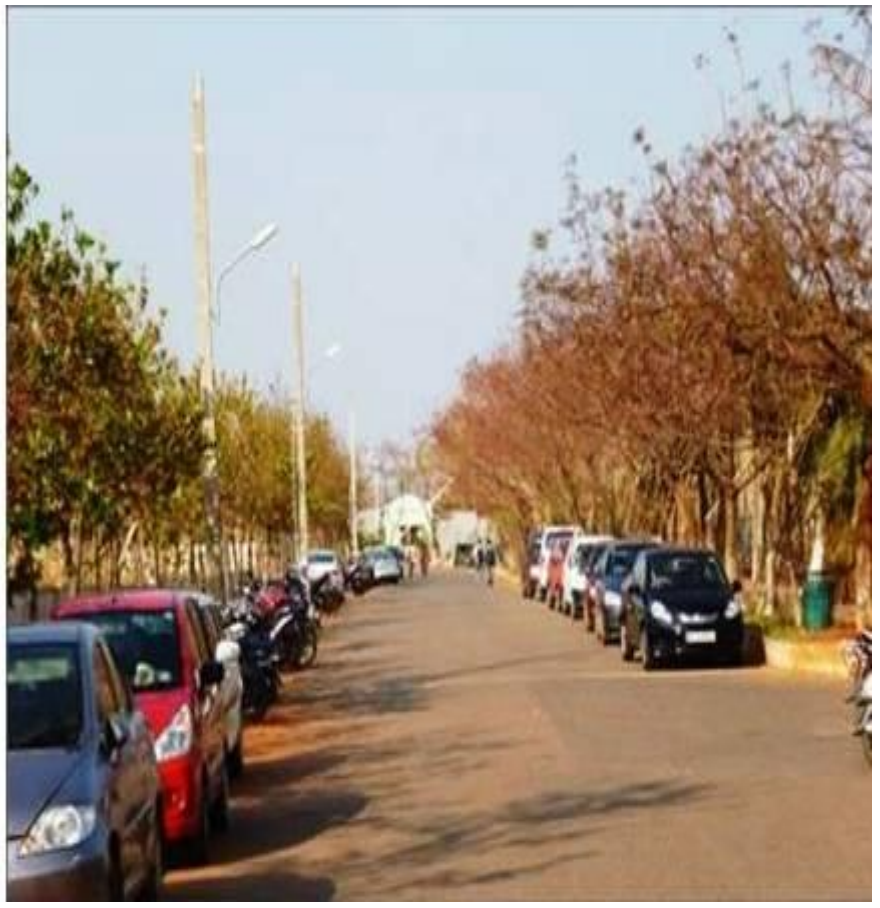

(b)

Fig 15 (a) A building crushed by uprooted Eucalyptus trees in front of the Advances Sciences Bhawan in the Andhra University campus (b) Salt spray damage to trees in the Gitam University campus.

\section{CONCLUSION}

Widespread damage to buildings, infrastructure and landscape elements along the fragile Visakha-Bheemli coastal corridor post Cyclone Hudhud is seen from the postcyclone damage assessment study. Buildings need to be structurally sound and aerodynamically designed to withstand the impact of strong cyclonic winds. Undergrond power cables would prevent damage to power lines from falling trees. Trees that are wind resistant and tolerant to salt spray should be selected for planting in coastal areas. The planting of shelter belts and protection of indigenous groundcovers along the coast would help in mitigating the adverse impact of strong winds to some extent and also prevent coastal erosion. Such measures would help in reducing damage to buildings, infrastructure and green cover from future cyclones.

\section{REFERENCES}

[1] Mohan. K, Gairola. A and Kwatra. N. (2014) Wind Damage to Trees at Visakhapatnam by Cyclone Hudhud, Proceedings: $7^{\text {th }}$ National Conference on Wind Engineering ( NCWE-2014), Thapar University, Patiala, 21-22 November 2014, pp. 272287.

[2] The HINDU, October 14,2014 Your wait for power may get longer. 